\title{
Payroll Processing Tagmemics in SAP HR
}

\author{
J. Anitha ${ }^{1}$, J. Saritha ${ }^{2}$ and Namkyun Baik ${ }^{3 *}$ \\ ${ }^{1}$ Department of Information Technology, Vignan's Institute of Information \\ Technology, Visakhapatnam, AP, India \\ ${ }^{2}$ Sr. SAP HR Consultant, SAP - Payroll, ADP, India \\ ${ }^{3}$ Korea Advanced Agency of Convergence Technology, \\ IT Venture Tower, 135 Jungdae-ro, Songpa-gu, Seoul, South Korea \\ 1anithanv28@gmail.com, ${ }^{2}$ saritha.jalumuri@gmail.com, \\ ${ }^{3}$ white-knight@naver.com
}

\begin{abstract}
This paper explains the basic Concepts of Payroll and the terms \& terminologies used in Payroll processing. To Understand the Payroll concepts in SAP HR and have a complete overview of the different features in the Payroll module. SAP ERP is built on the NetWeaver technology. SAPNetWeaver is used as a technology platform for integration and as an application infrastructure with open connections to Microsoft .NET and IBM WebSphere. The Payroll relies upon an all inclusive fund driver. This back driver is adjusted for each country. The country specific fund drivers consider the statutory and administrative bearings of a country. Since the back driver has a confined structure, you can use the Customizing abilities to quickly change the fund methodology to meet the particular requirements of your wander. Back DRIVER is a Special report for Payroll. $S A P$ has made country specific back drivers, which rely upon report RPCALCXO. With country specific reports the penultimate character in the name insinuates the country pointer (for example, $D$ for Germany, $F$ for France). Report RPCALCxO can figure irregular portions and moreover off-cycle fund runs (Bonus figurings). The country specific back drivers contain the data. After the fund run, you can trade the fund results to Financial Accounting.
\end{abstract}

Keywords: Enterprise Resource Planning (ERP), Systems Application Product (SAP), HR, Wagetype, Payroll processing, Payroll control record, Income Tax computation, Posting to Accounts

\section{Introduction to WAGETYPES}

In a wide sense, a wagetype essentially holds a bit of information, for example, rate, number, as well as sum. Be that as it may, all the more particularly, a wagetype has many characteristics that control how it is controlled and prepared. At last however, it winds up as a question in the finance comes about database that stores a rate, number, or potentially sum.

The most commonplace utilization of a wagetype is to store the measures of income, conclusions and duties in a workers paycheck. A people base pay is put away in a wagetype, the measure of their United Way finding is put away in a wagetype, and their assessable wages and charges are put away in wagetypes. Wagetypes, as the essential information component for representative paychecks, are likewise mapped to FI/CO

Received (November 30, 2017), Review Result (January 6, 2018), Accepted (January 17, 2018)

* Corresponding Author 
records to record the charges and credits coming about because of the paycheck and provided details regarding the $\mathrm{W}-2$ and other tax documents.

Wagetypes can likewise be utilized to store measurable information, for example, the quantity of hours worked in a payroll interval, the normal week after week compensation for as far back as a half year, or the measure of wages qualified for a benefit sharing figuring. Wagetype properties are put away in a few tables, yet the focal table is T512W. Considerably more time will be spent on different parts of T512W.

There are three classes of wagetypes model, specialized, and client. Show wagetypes are conveyed by SAP for clients to use as rules for making their own particular wagetypes. They generally begin with a letter and SAP may include, erase or refresh them in framework redesigns or HRSPs. Specialized wagetypes dependably begin with the/image, and are conveyed by SAP. They are planned for certain standard preparing in finance, and keeping in mind that you can alter them, SAP may likewise refresh them amid redesigns or HRSPs. So in the event that you ever (I mean EVER) change a specialized wagetype, check it after each update or HRSP to ensure regardless it has the characteristics you need. What's more, never erase a specialized wagetype. Client wagetypes dependably begin with a number and these are wagetypes that SAP does not change amid updates and HRSPs SAP infrequently transforms them in redesigns and HRSPs. Client wagetypes are for all the organization particular finance installments and derivations.

Wagetypes denote various payments and deductions that are applicable in an organization context. System generates various wagetypes in the context of gross and net payroll processing.

- /101 - Gross Payroll

- /3F1 - Employee PF

- /3F2 - Employee Voluntary PF

- /3E1 - Employee ESI Contbn.

- /3W1 - Employee LWF Contbn.

- /3P1 - Profession Tax

- /460 - Income Tax

- /462 - Voluntary Income Tax

- $/ 550$ - Statutory Net Pay

- /110 - Non Statutory Deductions

- $/ 560$ - Net Pay

- /559 - Bank Transfer Amount

- /557 - Net Pay in Cash

\section{SAP Allowance Grouping:}

\section{Grouping of employees for whom the following are similar}

- Applicability of Payments

- Computation methodology of

- Payments

- Computation Number for the

- Payment

\section{Allowance grouping definition for India}

- ESG for CAP - 3

- Pay Scale Type 


\section{Pay Scale Area}

- 01 - Hyderabad

- 02 - Pune

- 03 - All India

Pay Scale Group

- 01 -Hyd Workmen

- 02 -Hyd Casual

- 03 -Hyd Contract

- 04 -Staff M6-M8

- 05 -Staff M1-M5

- 06-Hwr SSW

- 07 -Hwr SW1

- 08 -Hwr SW2

- 09 -Hwr HSW

- 10 -Workmen

- $11-\mathrm{M} 1-\mathrm{M} 8$

- 12 -Staff Trainee

- 13 - Temporary Staff

Table 1. Salary Structure

\begin{tabular}{|l|l|l|l|l|l|}
\hline $\begin{array}{l}\text { Pay Scale } \\
\text { Area }\end{array}$ & $\begin{array}{l}\text { Pay } \\
\text { Scale } \\
\text { Type }\end{array}$ & $\begin{array}{l}\text { ESG Gpg. } \\
\text { For CAP }\end{array}$ & $\begin{array}{l}\text { Pay } \\
\text { Scale } \\
\text { Group }\end{array}$ & ALGRP Key & $\begin{array}{l}\text { ALGRP } \\
\text { Definition }\end{array}$ \\
\hline 01 & 01 & 3 & 01 & AL01 & VtzWorkmen \\
\hline 01 & 01 & 3 & 02 & AL02 & Vtz Casual \\
\hline 01 & 01 & 3 & 03 & AL03 & Vtz Contract \\
\hline 01 & 01 & 3 & 10 & AL10 & Vtz M6_M8 \\
\hline 02 & 01 & 3 & 06 & AL06 & Vtz M1-M5 \\
\hline 02 & 01 & 3 & 07 & AL07 & Hwr SSW \\
\hline 02 & 01 & 3 & 08 & AL08 & Hwr SW1 \\
\hline 02 & 01 & 3 & 09 & AL09 & Hwr SW2 \\
\hline 99 & 01 & 3 & 04 & AL04 & Hwr HSW \\
\hline 99 & 01 & 3 & 05 & AL05 & Workman \\
\hline 99 & 02 & 3 & 11 & AL11 & M1-M8 \\
\hline 99 & 02 & 3 & 12 & AL12 & Trainee \\
\hline 99 & 01 & 3 & 13 & AL13 & $\begin{array}{l}\text { Vtz Temporary } \\
\text { staff }\end{array}$ \\
\hline
\end{tabular}




\section{Payroll Areas:}

Payroll areas are used to group together employees for whom payroll is performed at the same time, and also to set the dates for the payroll period. Employees from different employee subgroups can belong to the same payroll area.

\begin{tabular}{|c|c|}
\hline Payroll Area & Description \\
\hline 01 & VignanVtz-Workmen \\
\hline 02 & VignanVtz Staff \\
\hline 03 & Vignan Senior Mgt \\
\hline 04 & VignanHwr Workmen \\
\hline 05 & VignanHwr Staff \\
\hline 06 & M1 to M6 \\
\hline 07 & Others \\
\hline 99 & No Payroll \\
\hline
\end{tabular}

\section{SAP Payroll Process:}

- The payroll program reads the master data and time data infotypes, which means thatchanges effected during the payroll run could jeopardize the accuracy of the payroll results.

- It also means that payroll should not be run duringmaster data maintenance. This is controlled by Payroll Control Record.

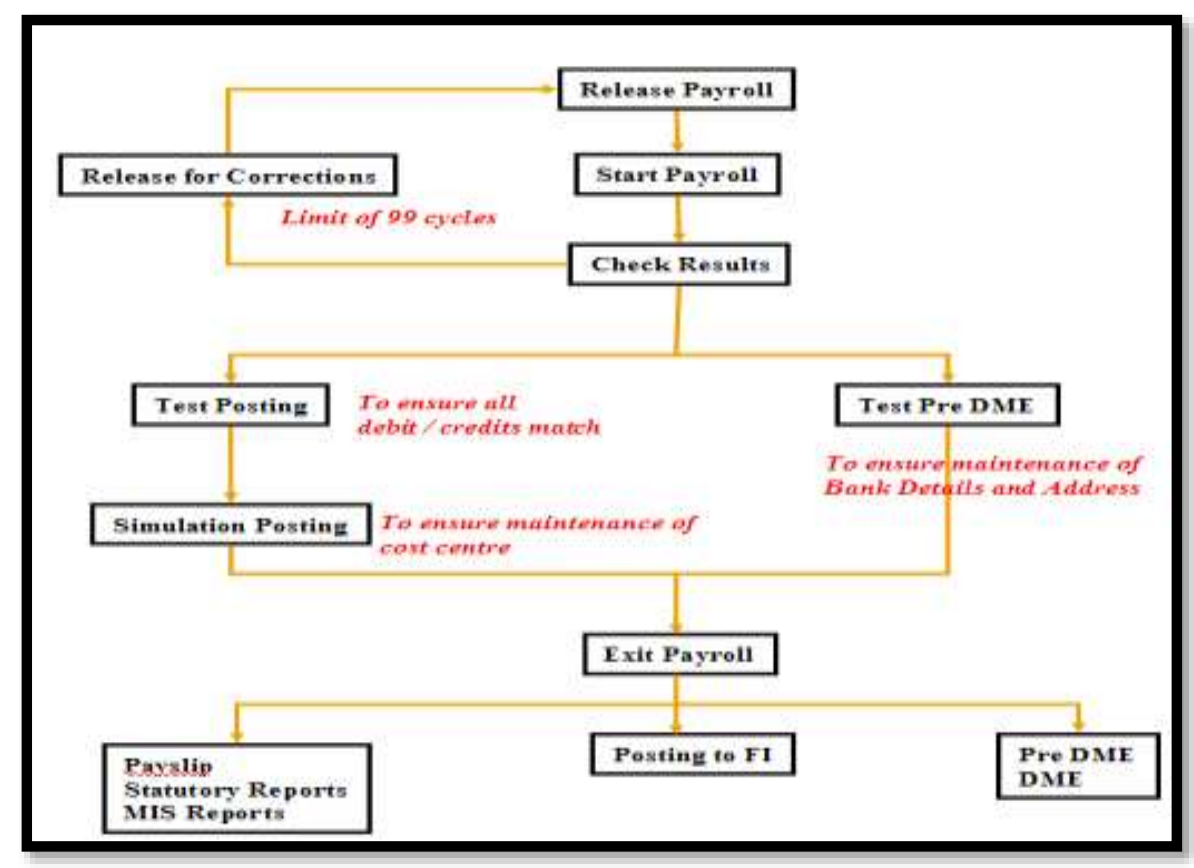

Figure 1. Payroll Process

\section{Payroll Simulation}

Transaction - ZHRPAYROLL [with Test Run (no update) option selected]

- Simulating a payroll run enables users to display and print remuneration statements

- Master Data and Time Data are not locked 
- Payroll periods are not counted in payroll control record

- A Simulation Payroll Run (without Display Log and Payslip options) is recommended.

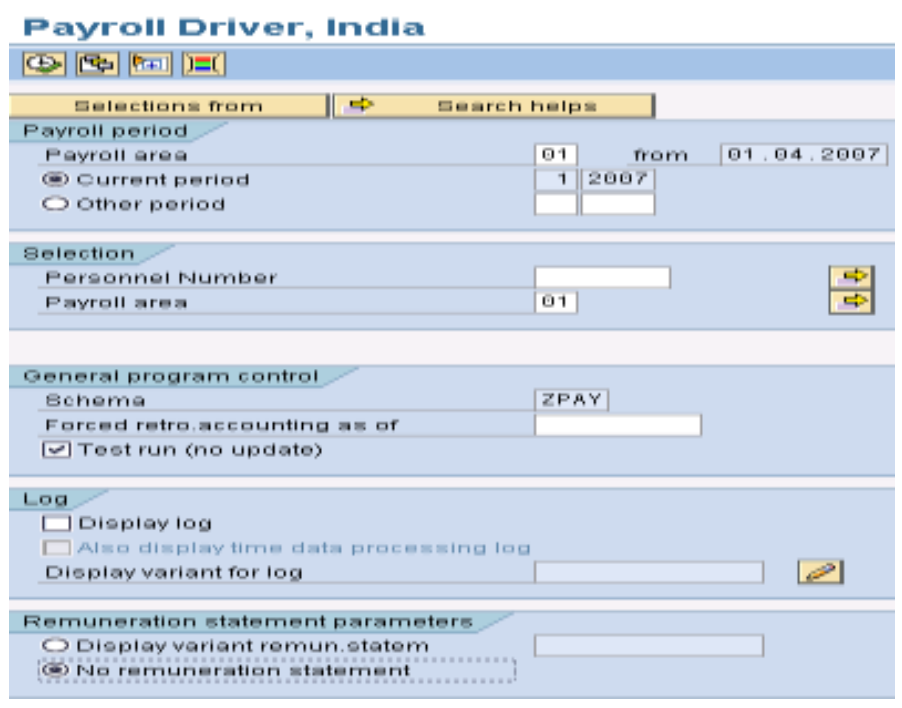

Figure 2. SAP HR Service Package

\section{Release Payroll:}

Transaction - PC00_M99_PA03_RELEA or PA03

- When a Payroll Area is Released forPayroll, users are prevented from changing infotype data records if such changes affect the payroll past or present

- Off Cycle payroll cannot be run in thatmonth for the Payroll Area for which the Payroll Control Record has been released for Regular Payroll

- Payroll Area should be released forPayroll only when the monthly regular payroll processing is due.

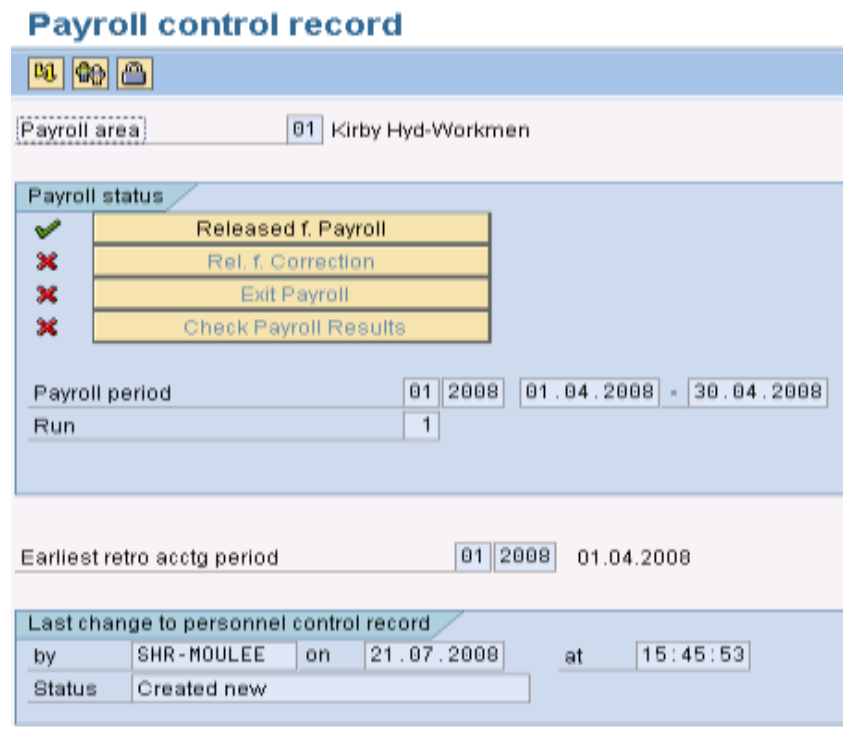

Figure 3. SAP HR Service Package 


\section{SAP Start Payroll:}

Transaction - ZHRPAYROLL(without selection of Test Run option)

- Always select 'Current Period' only Do not enter Personnel Numbers if you are running for the entire Payroll Area

- Do the first run without Display Log and Payslip Options

- If payroll run indicates errors, re-run payroll only for the error employees withDisplay Log and Payslip option (if the no. Oferror cases is upto 30 employees)

- After 'Release for Corrections', re-runpayroll for all employees in a payroll arearather than error employees only.

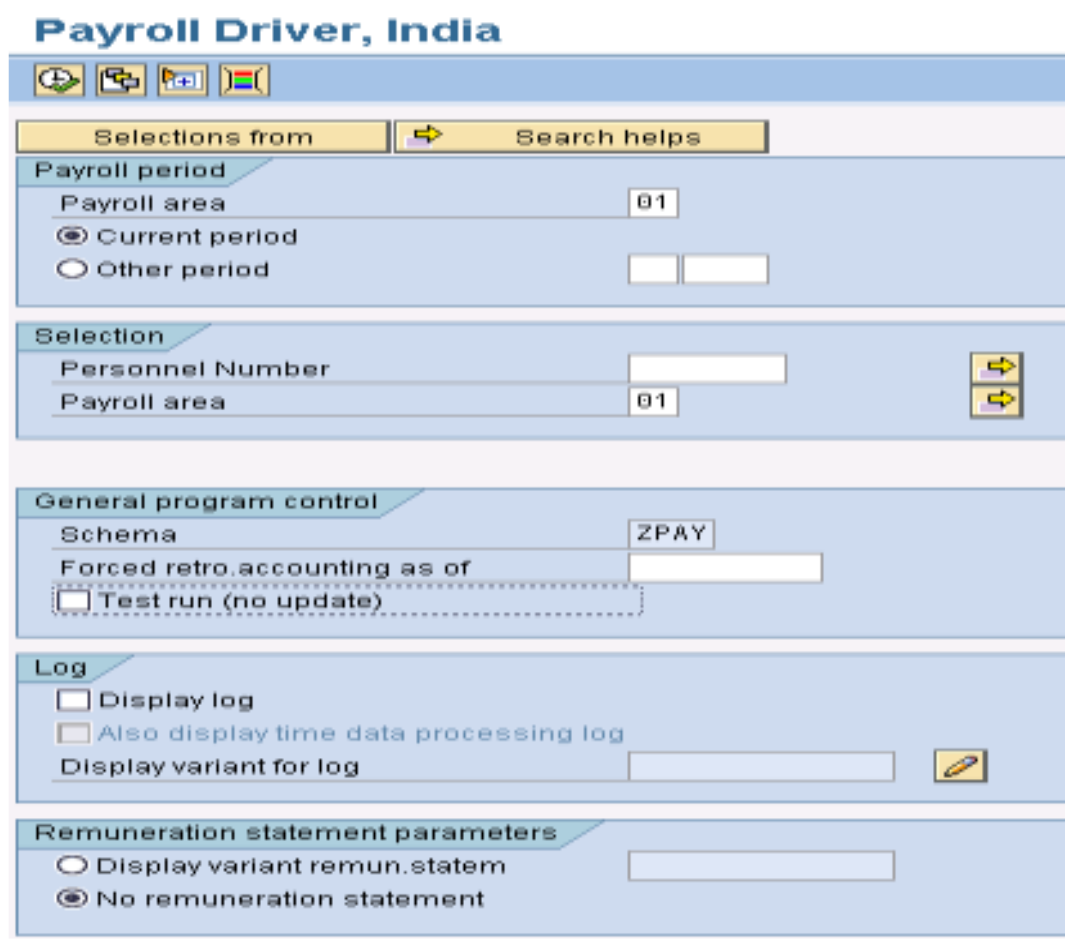

\section{Figure 4. SAP Start Payroll}

\section{SAP Check Results}

Transaction - PC00_M99_PA03_CHECK or PA03

- Once the payroll is run for all employees in a payroll area, the status can be set to Check Results

- This status prevents running of Payroll too

- Results of the Payroll Run can be analysed using Wagetype Reporter (ZHRWTREP).

Comparison across payroll periods also can be done to using this report. 


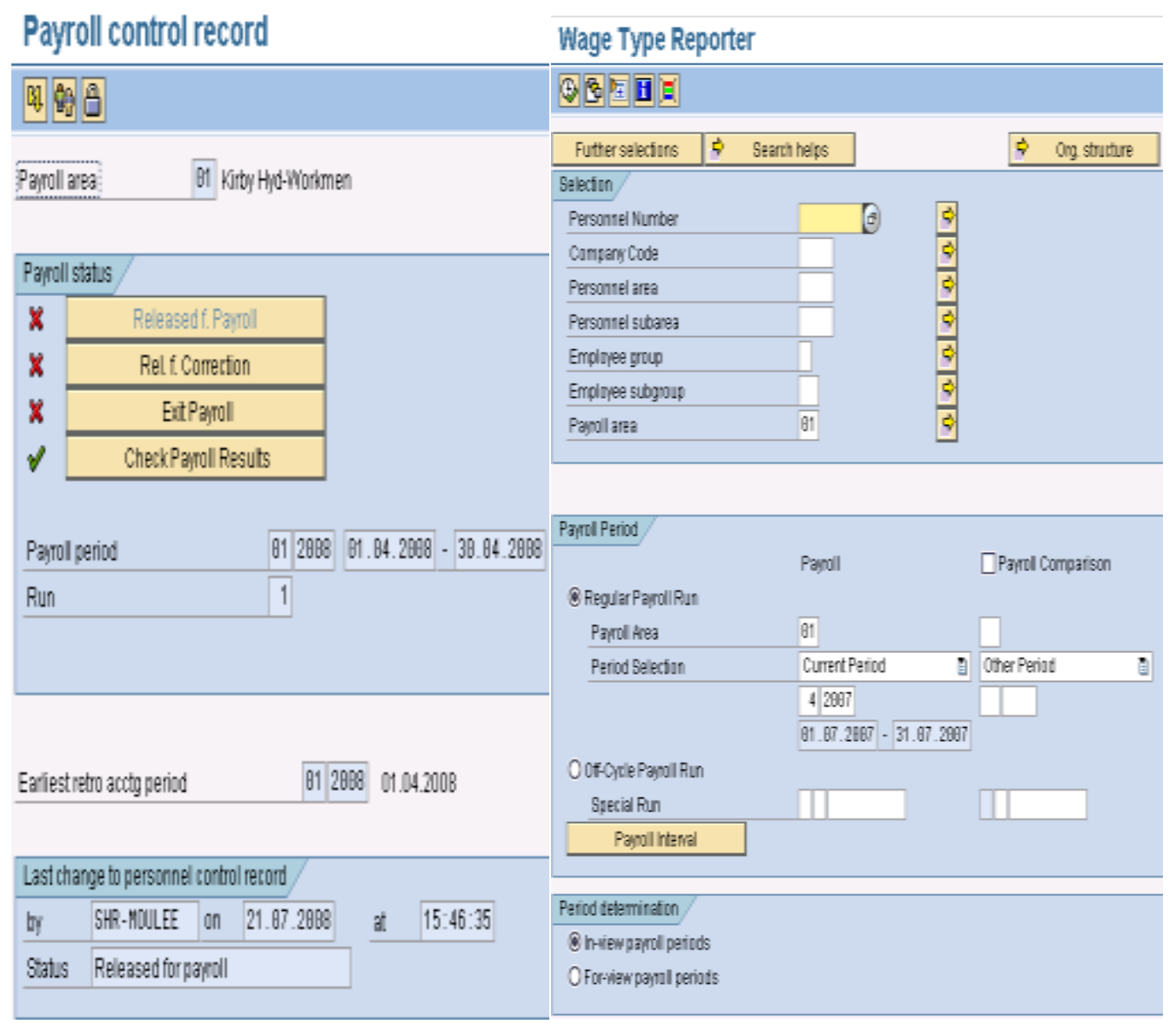

\section{SAP Payroll Log:}

- The payroll results are displayed in a tree structure. This makes it easier for you to analyze and get an overview of the payroll results

- The log includes a table of contents, which is presented as tree structure. The nodes within the tree structure enable you to access the detailed information that you require. The headers within the structure are designed to help user with troubleshooting and to facilitate navigation within the log.

- If an error occurs when a personnel number is processed, the log is expanded at the appropriate place and an error message is displayed

- Do not run Payroll 'with log' for more than 30 employees at a time, as this might impact 


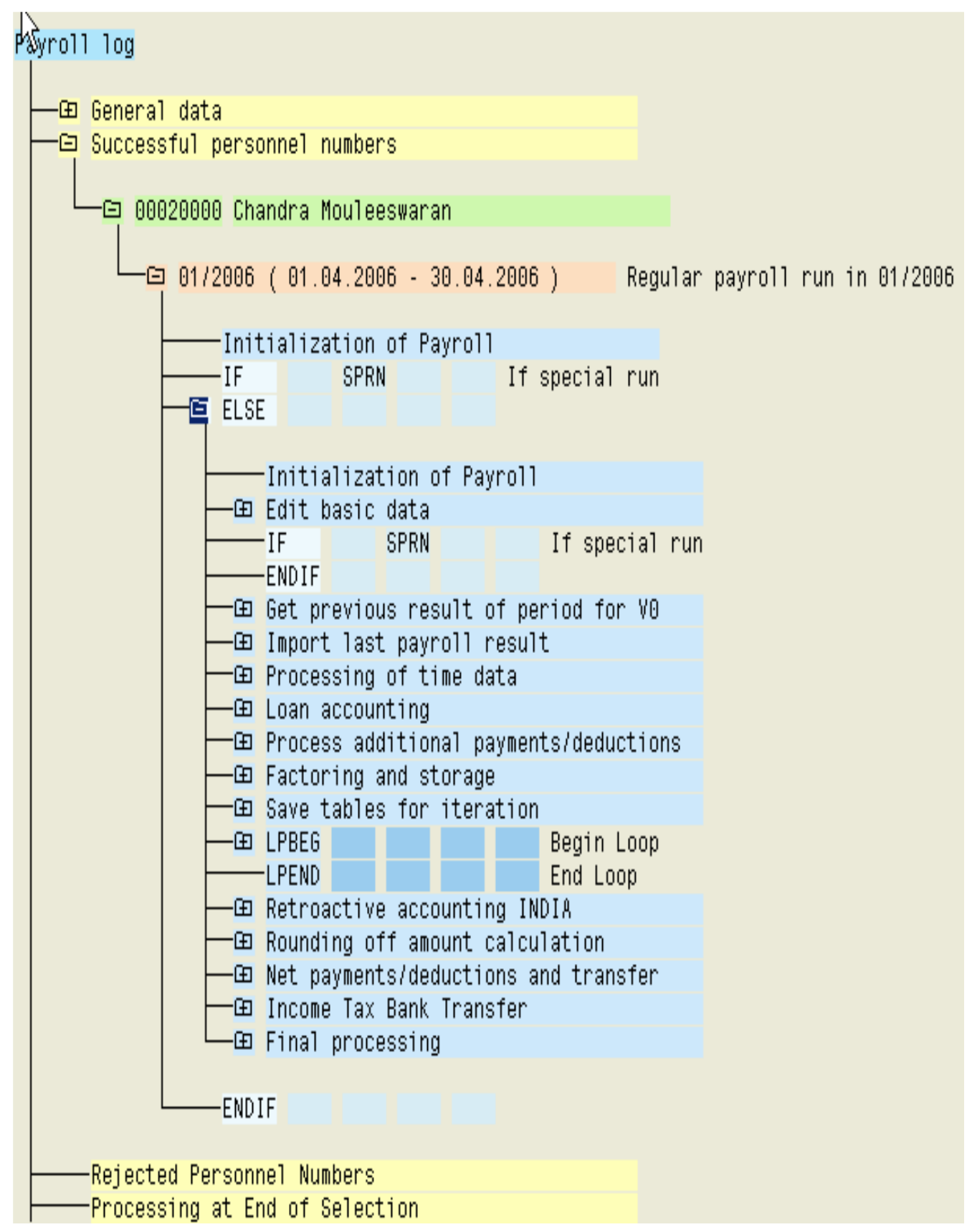

Figure 5. Payroll Log 


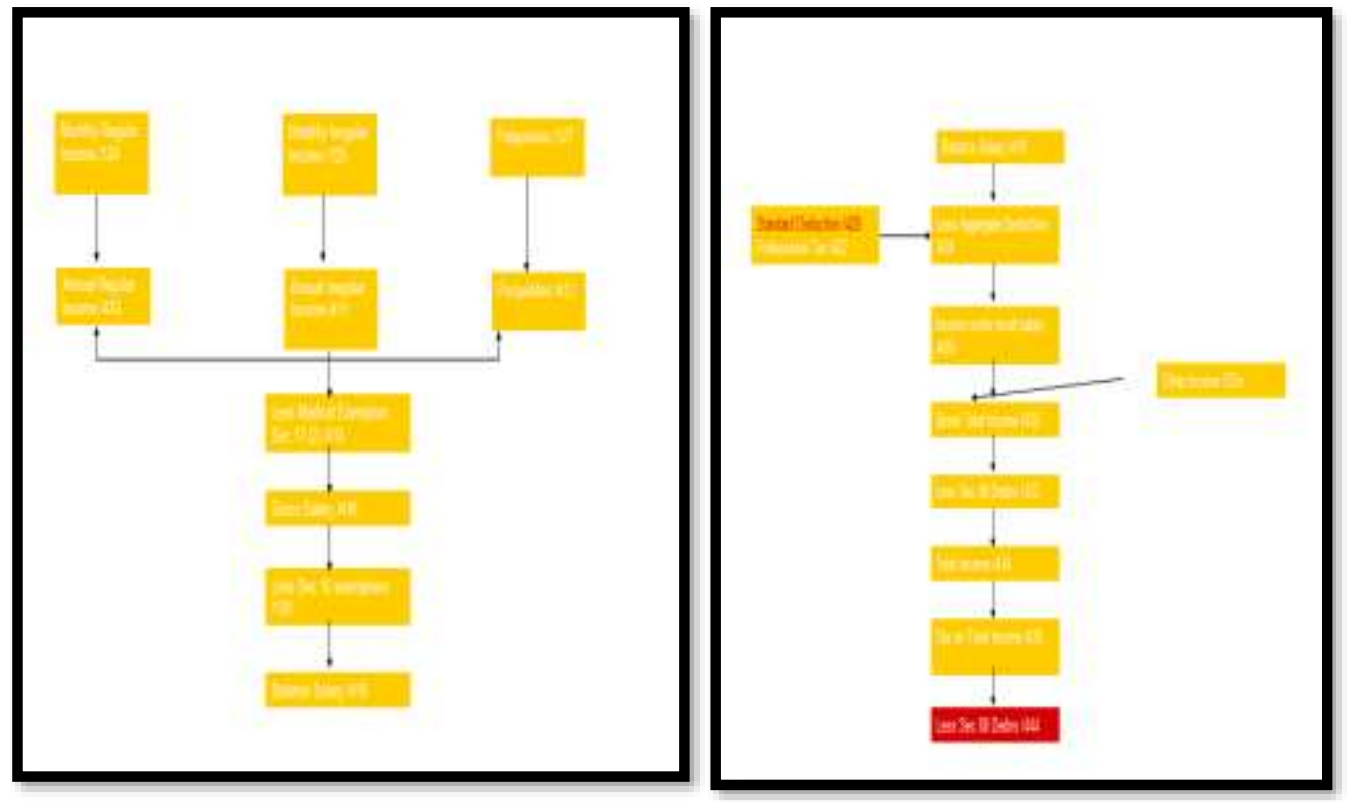

Figure 6. Income Tax Computation

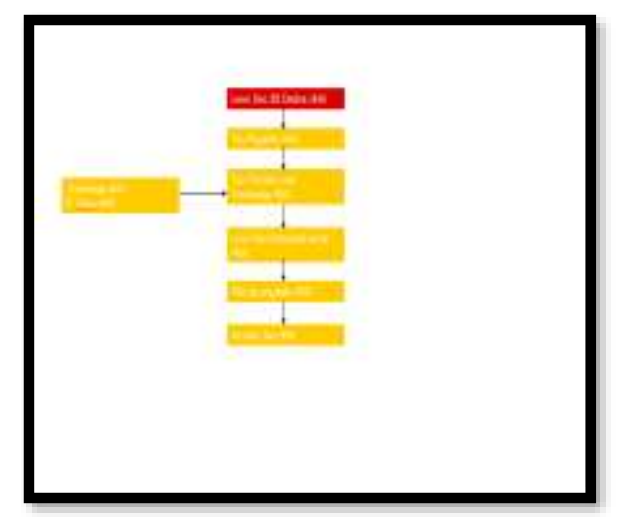

Figure 7. Income Tax Computation

\section{Release for Correction:}

- If errors are identified during 'Check Payroll Results', the Payroll Control Record should be 'Released for Correction'

- When the status of Payroll Control Record is 'Released for Correction' users can carry out employee master data changes in the payroll past and present

- Once master data corrections are completed, Payroll Area should be 'Released for Payroll'

- Everytime user goes through the cycle of 'Released for Correction - Released for Payroll', the Run count gets incremented.

- It is recommended that a Simulation Payroll with Payslip is option is run (for employees for whom corrections were carried out) prior to Release for Payroll. This is to optimize on no. of Payroll Runs. 


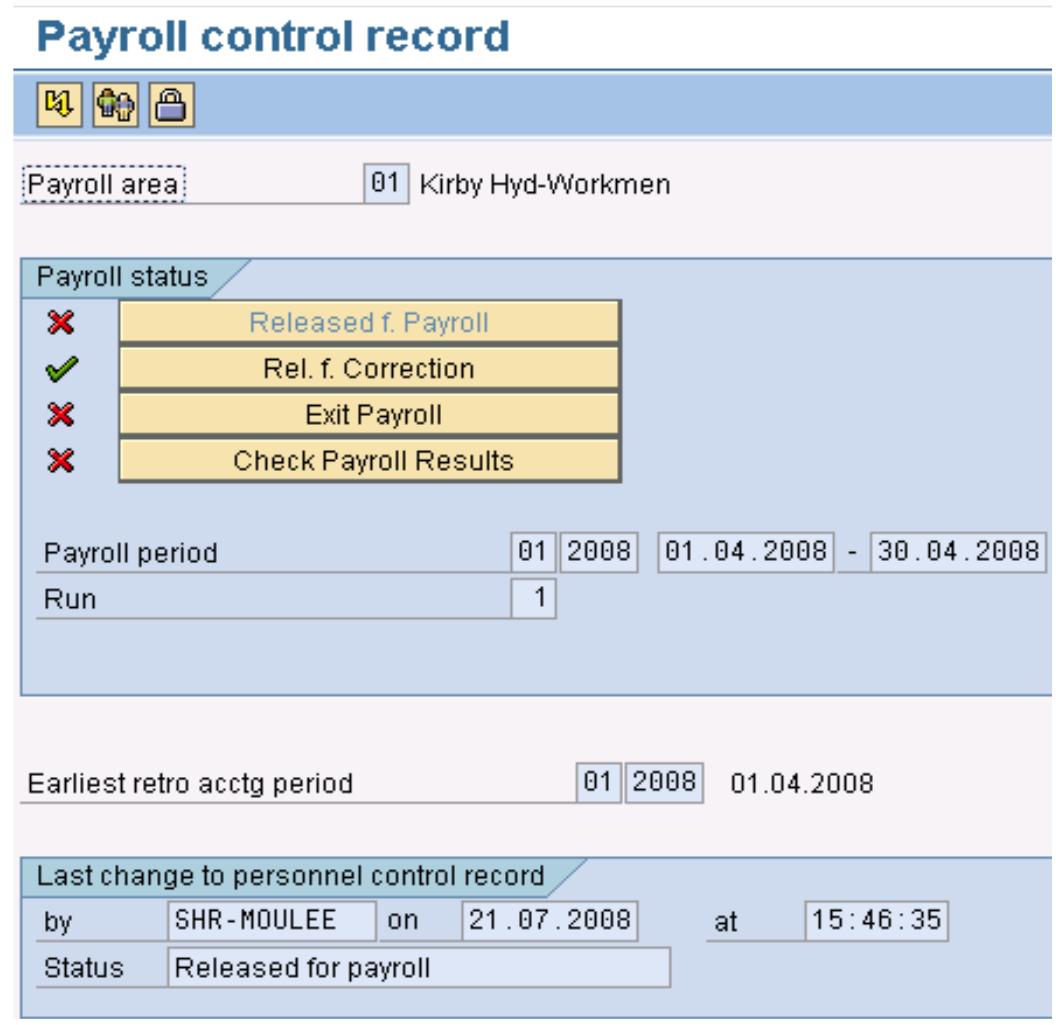

\section{Test Pre DME}

- Preliminary Data Medium Exchange program should be run prior to Exit of Payroll

$>$ with TEST selected and

$>$ 'Set flag for transfers' not selected

- This is to ensure that Address Detail has been maintained for all employees for whom payroll has been processed as part of payroll run.

- Non maintenance of Address Data for an employee will impact generation of Bank Transfer Statement for that employee

\section{Test Posting}

Transaction -With 'Type of Document Creation' as T

- Test Posting Run should bedone prior to Exit of Payroll

- This is to ensure that all creditsand debits match as part of

Payroll Posting

- Enter Doc Date as last date ofthe month under consideration

- Output Log should be enabledto analyse error employees(not exceeding 30 employees at atime)

\section{Simulation Posting}

Transaction -With 'Type of Document Creation' as S

- Simulation Posting Run should be done prior to Exit of Payroll

- This is to ensure that all employees have been attached to a Cost Center

- Enter Doc Date as last date of the month under consideration

- Output Log should be enabled only to analyze error employees (not exceeding 30 employees at a time) 


\section{Exit Payroll}

Transaction - PC00_M99_PA03_END or PA03

- Exit Payroll function enables user to rerelease infotypes so that they can be maintained for the past and present.

- User cannot choose this function until the payroll has run successfully for all of the personnel numbers assigned to the selected payroll accounting area. If you attempt to choose this function and rejected personnel numbers exist, the system displays an error message. The error employees list can be obtained by clicking on icon in Payroll Control Record

- After payroll has been exited, user can change data for the period in question by performing retroactive accounting in a subsequent payroll period.

\section{Preliminary DME}

Transaction -(without 'TEST' option selected)

- Preliminary Data Medium Exchange program should be run after to Exit of Payroll

$>$ without TEST selected and

$>$ 'Set flag for transfers' selected

- The net pay of the employee along with Bank Details is stored in BT table of payroll cluster

- Preliminary DME is to transfer the BT table contents to three FI tables viz. REGUH, REGUP and REGUV

- Upon completion of Actual Pre DME, note down the Run Identification Number as seen in the log, which is used to generate Bank Statement.

\section{Log Display}

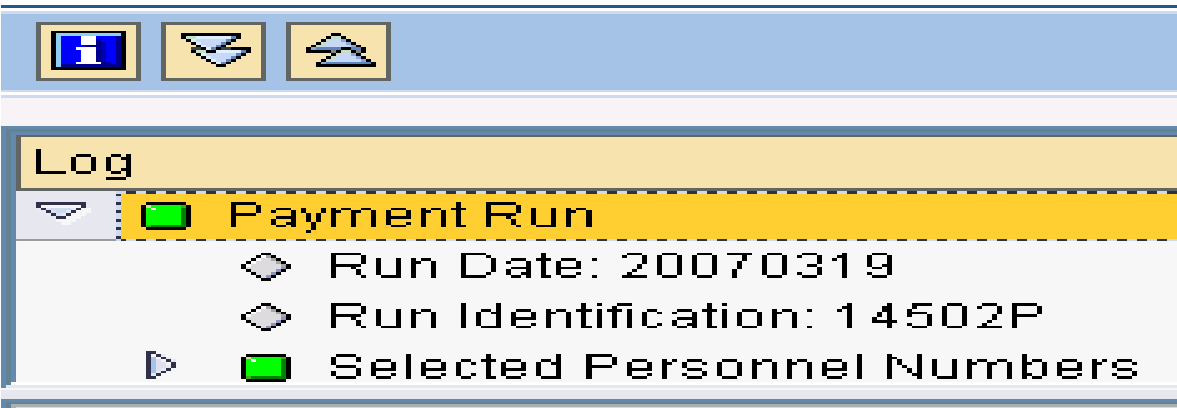

\section{Bank Statements:}

Transaction - ZHRBANKST (without 'TEST' option selected)

- Enter Payroll Area, Current Period, Company Code

- Enter the Run ID generated during actual Pre DME

- Select the appropriate Bank Key for generating the statement

- Statement will be generated as per requirement of bank selected

- Covering letter will also be generated as part of thestatement

- Option to Print or Download as Electronic Statement 


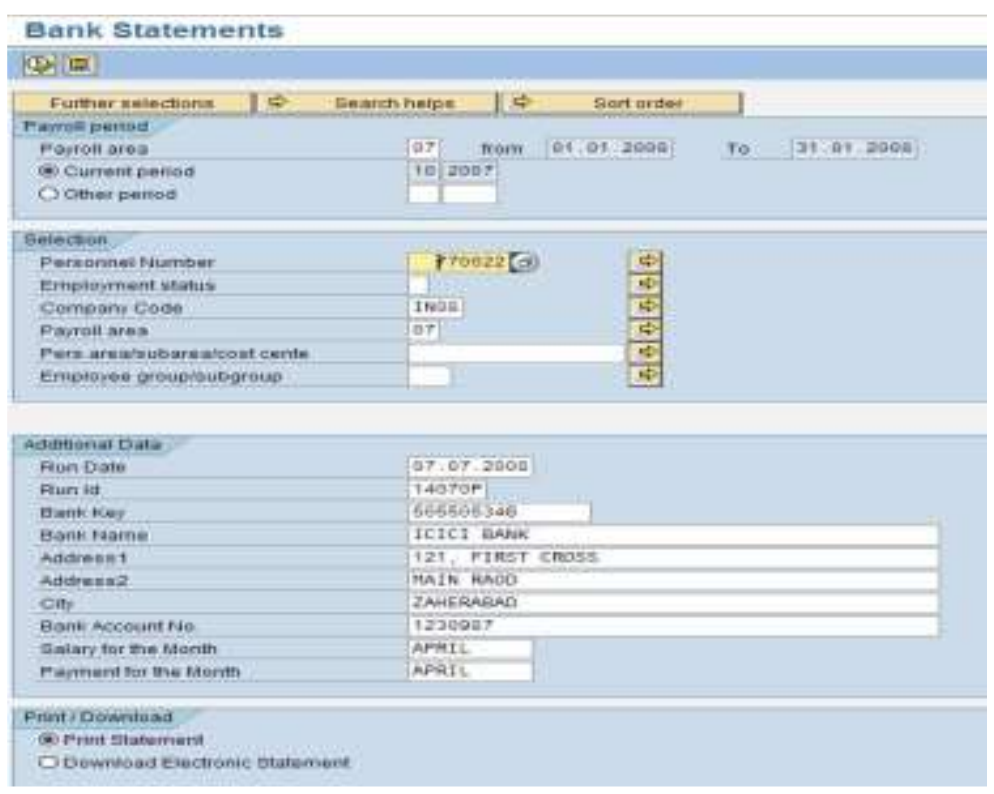

Figure 7. Bank Statement

\section{Posting to Finance (FI)}

Transaction - ZHRPOST With 'Type of Document Creation' as P

- Live Posting Run should be run after Exit of Payroll

- The following activities must be performed when posting payroll results to accounting:

$>$ Create posting run

$>$ Edit posting run

$>$ Check posting run

Check posting documents

Release posting documents

Post posting run

Check completeness of postings

- Document Type for Payroll Posting .Documents will be Payoll (PY)

\section{Edit Posting Run}

Transaction - PCP0

- After creating the posting run, you can check whether the payroll results for all employees have been correctly evaluated.

- Display the list of posting runs

- Check the required posting runs

- Status: If the posting run has a status other than "Documents Created", an error has occurred when creating the posting runs.

- History: Choose 'Display History'

- Attributes; Display attributes of a posting run

- The standard system only displays the posting runs that have been created and not yet posted. You can use a filter to change the display criteria for the list of posting runs. For example, you can display all posting runs, orposting runs that have been posted or deleted.

\section{Check Posting Documents}

- To display posting documents, double- click on 
posting run

- Posting Documents contained in the Posting Run are displayed

- Double click on the Posting Document to check

- Double click on line item within chosen Posting Document for details

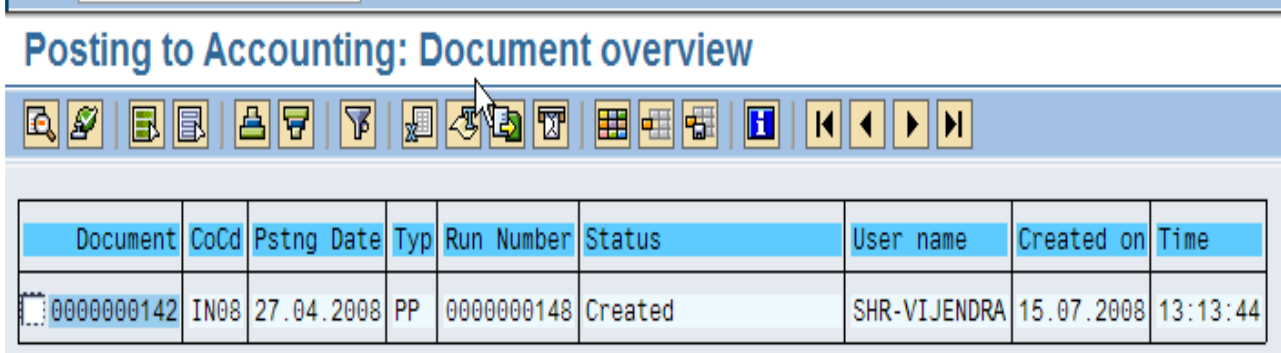

\begin{tabular}{|c|c|c|c|c|c|c|c|}
\hline \multicolumn{2}{|c|}{ Account Nunber with Text } & \multirow{2}{*}{$\begin{array}{l}\text { Co Accht } \\
\text { cctr 2a2838891e }\end{array}$} & \multirow{2}{*}{$\begin{array}{l}\text { Wage Type Long Text } \\
\text { 1990 Basic }\end{array}$} & \multirow{2}{*}{\begin{tabular}{r|} 
Pers. No. \\
7110
\end{tabular}} & \multirow{2}{*}{$\begin{array}{r}\text { Debit Aavont } \\
15,690.98\end{array}$} & Gredit Anount & \multirow{2}{*}{$\begin{array}{l}\text { Grey } \\
\text { INR }\end{array}$} \\
\hline ] 718380 & Direct Labour -Goods & & & & & & \\
\hline$\cdot 718389$ & Direct Labour -Goods & octr 2828388819 & 1980 Basic & & $15,808.98$ & & INR \\
\hline ] 718360 & Direct Labour - Coods & | octr $292838891 \theta$ & 1028 HRA & 7110 & $3,698.96$ & & INR \\
\hline$\cdot 710360$ & Direct Labour - Goods & cctr 2928388910 & $102 \theta$ HRA & & $3,609.08$ & & INR \\
\hline 718309 & Direct Labour - $600 d s$ & Cotr 292838891日 & 1838 Conveyance $A 17 \mathrm{~s}$ & 7116 & $1,580.96$ & & INR \\
\hline$\cdot 710380$ & Direct Labour -Goods & octr 2928388910 & 183日 Conveyance $A 17 \%$ & & $1,590.06$ & & INR \\
\hline C. 718306 & Direct Labour -Goods & Cotr 2828388918 & | 1055 Washing Allowek & 7118 & $1,690.60$ & & INR \\
\hline$\cdot 710309$ & Direct Labour -Goods & octr 2928388919 & 1955 Washing Allowes & & $1,690.80$ & & INR \\
\hline 7] 719300 & Direct Labour-Goods & cotr 282838891日 & 1104 Children Educak & 7110 & $2,589.98$ & & INR \\
\hline$\cdot 710389$ & Direct Labour - Goods & CCtr 282838881日 & 1184 Children Educak & & $2,590.98$ & & INR \\
\hline .. & & & & & $23,608,90$ & & INR \\
\hline
\end{tabular}

Display Payroll Posting Document

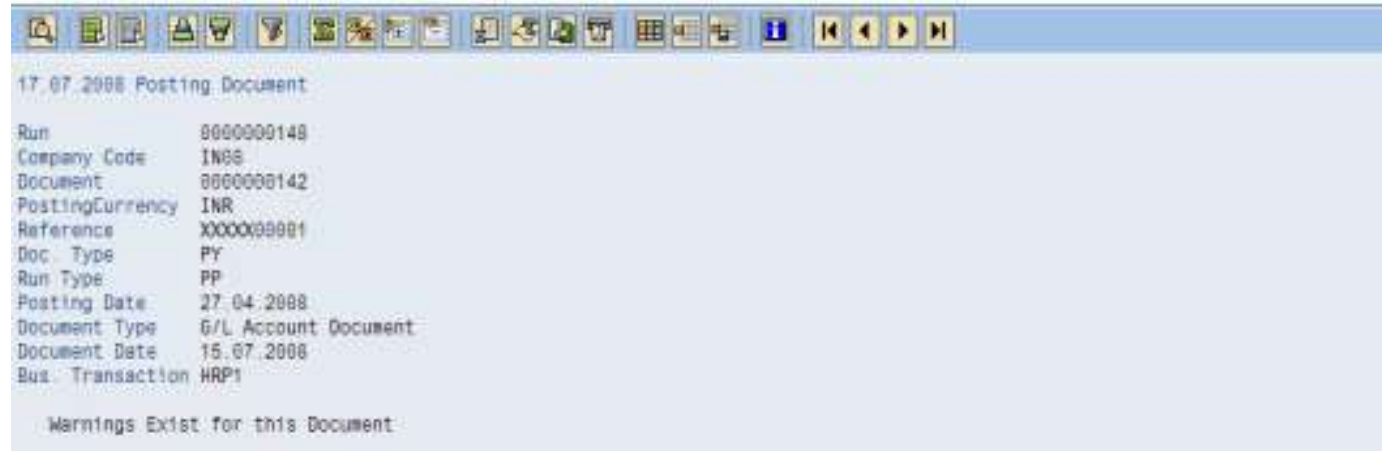

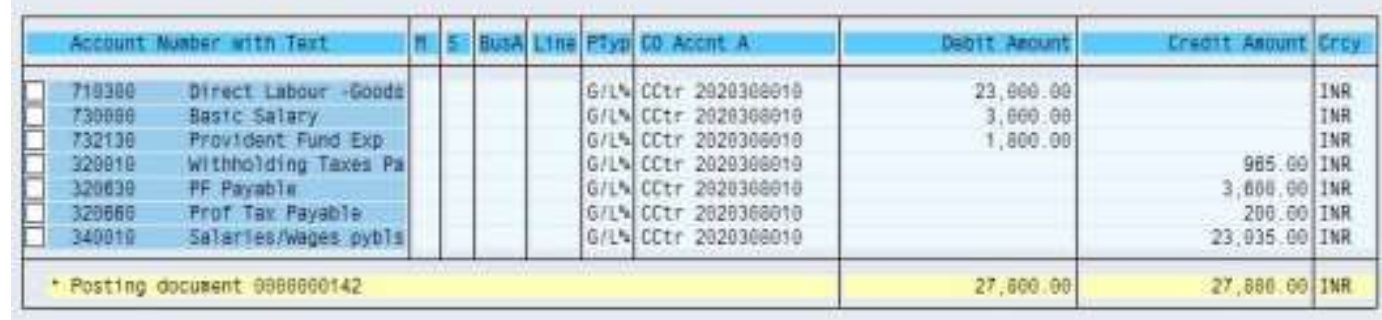

17 6r aebe Posting Drcuant

Total of Alt Docusents

\begin{tabular}{|c|c|c|c|}
\hline 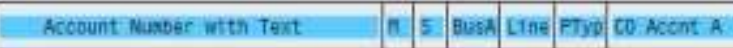 & Dabit Ancunt & Creost Anount & tercy: \\
\hline * & $27,660,00$ & 27.884 .50 & INR \\
\hline
\end{tabular}




\section{Release Documents}

- Select the documents contained in a Posting Run

- Click on button to release documents

- Confirm Release of Documents in the pop up by system

- Documents status changes from Created to Released

Posting to Accounting: Document overview

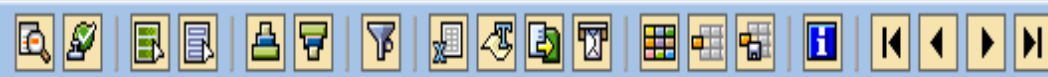

\begin{tabular}{|c|c|c|c|c|c|c|c|c|}
\hline Document & $\operatorname{coc} d$ & Pstng Date & Typ & Run Number & Status & User name & Created on & Time \\
\hline 00000000189 & ING6 & 27.06 .2008 & $\mathrm{PP}$ & 0000000191 & Created & SHR-MOULEE & 21.07 .2008 & $18: 17: 31$ \\
\hline
\end{tabular}

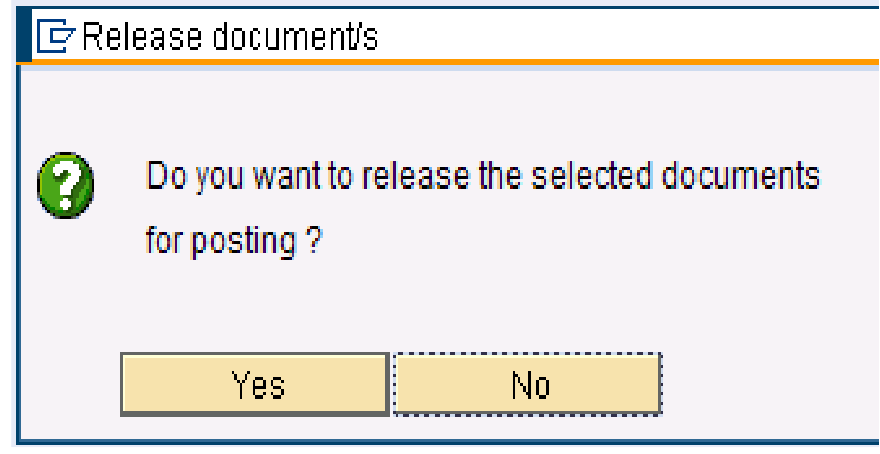

\section{Posting to Accounting: Document overview}

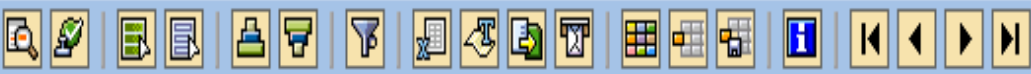

\begin{tabular}{|c|c|c|c|c|c|c|c|c|}
\hline Document & $\operatorname{coc} d$ & Pstng Date & Typ & Run Number & Status & User name & Created on & Time \\
\hline 00000000189 & INOG & $27.06 .2008 \mid$ & PP & 90909090191 & Released & SHR-MOULEE & 21.07 .2908 & $18: 17: 31$ \\
\hline
\end{tabular}

\section{Post Posting Run}

- Select the Posting Run to Post

- Click on button to post Posting Run

- Select option to post Immediately in the system pop up

- Posting Run status changes to Documents Posted

Display posting runs

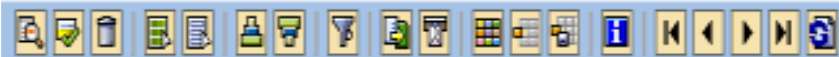

\begin{tabular}{|c|c|c|c|c|}
\hline \multicolumn{5}{|l|}{ Typ Nane } \\
\hline Selected E Run Nunber Text for Run & Run infornation & Sin Status & St User nane & Created on Tine \\
\hline \multicolumn{5}{|l|}{ PP Payroll posting } \\
\hline 1. $\quad 8008800191$ & Phrea 01/63/2098 & [Docunents posted & 50 SHR-MOULEE & $21.07 .2008 \quad 18: 17: 31$ \\
\hline
\end{tabular}


Displaying Accounting Documents

- Double click on the relevantPosting Run

- Select the Documentcorresponding to which

- Accounting Document needs tobe viewed

- Select Go To ->AccountingDocuments from Menu Bar

- Select Accounting or Costing Document to view

\section{Payslip}

Transaction - ZHRPAYSLIP

- A clear list of payments and deductions effected during a payroll run for an employee are published in the Payslip

- Payslip also carries Leave and Loan Details

- Form 16 Summary is published in Payslip for employees to carry out tax planning

- Payslips will be generated in PDF format and stored in the local disk of the user computer

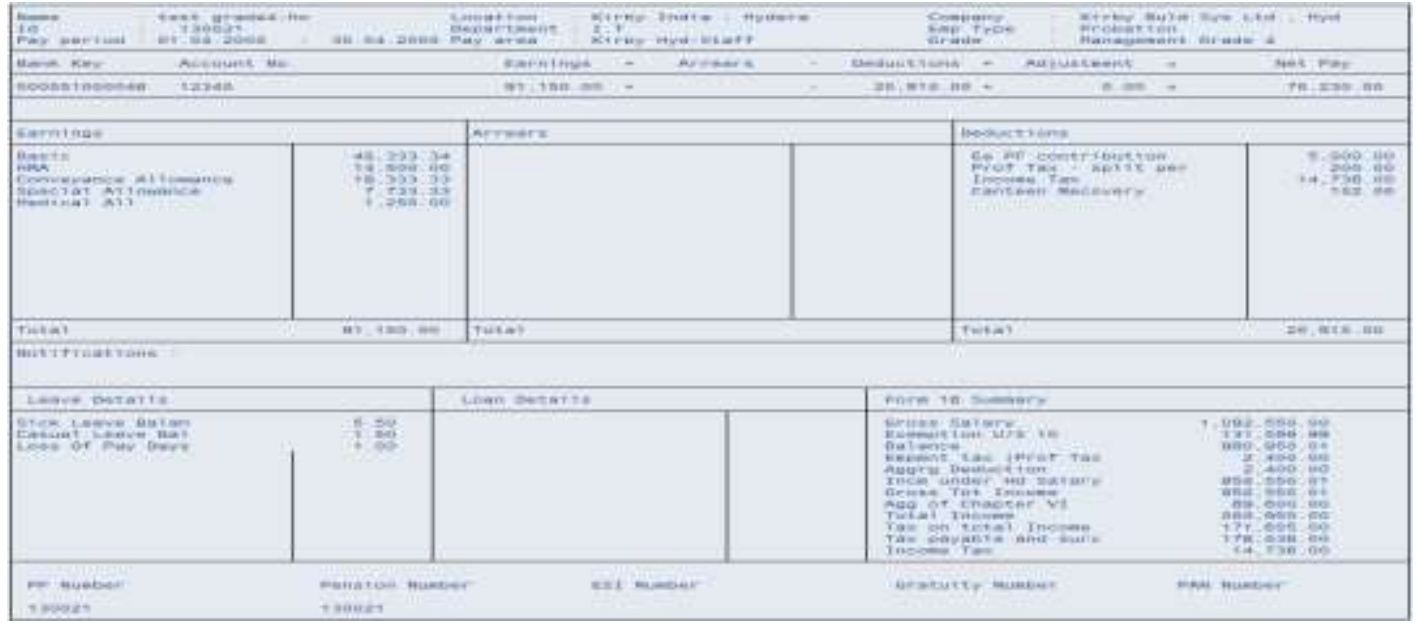

Notification in Payslip

- Maintain employee specific notifications in infotype 0128 -subtype 2 (Personal Notifications)

- Maintain generic notifications in the 'Messages' space provided in ZHRPAYSLIP selection screen

\section{Off Cycle Payroll}

- Irregular payments like claims, advances, bonus etc. can be paid to employees through off cycle payroll, on any day prior to monthly regular payroll

- Any off cycle payment or deduction can be made only through Additional Offcycle Payments (infotype 0267)

- Pre-condition to run off cycle payroll is that the payroll control record should be in'ExitPayoll' status for the preceding month

- Offcycle payroll cannot be run in a month once the payroll control record is 'Released for Payroll' for that month

- Off cycle reason will always be 0002 - Bonus in case of India

- The following are the steps involved in offcycle payroll

Start Payroll 
Test Posting

Simulation Posting

Test Pre DME

Live Posting

Live Pre DME

Bank Statements

Payslip Generation

\section{Full and Final Statement}

- Full and Final Settlement is to be done through Regular Payroll

- In case of mid month separation, payroll user can run full and final settlement workbench

- Subsequently, HR user can run the Separation Action

- Once these two activities are complete, payroll user can run a Simulation Payroll with Payslip option, to ascertain the Net Pay for the employee

- Payroll user can process the Net Pay as an offcycle payment, using info type 0267and wagetype 1317 (Salary Advance)

- Payroll user can also print the payslip generated during Simulation Payroll and hand over to the separating employee.

- Subsequently, payroll user will have to record a recovery of the same Net Pay amount through Salary Advance wage type in infotype 0015

- When the monthly regular payroll run is done subsequently, the Net Pay for the separated employee will be zero

- Also payroll accounting for full and final settlement will be taken care at the time of regular payroll.

\section{MIS Reports}

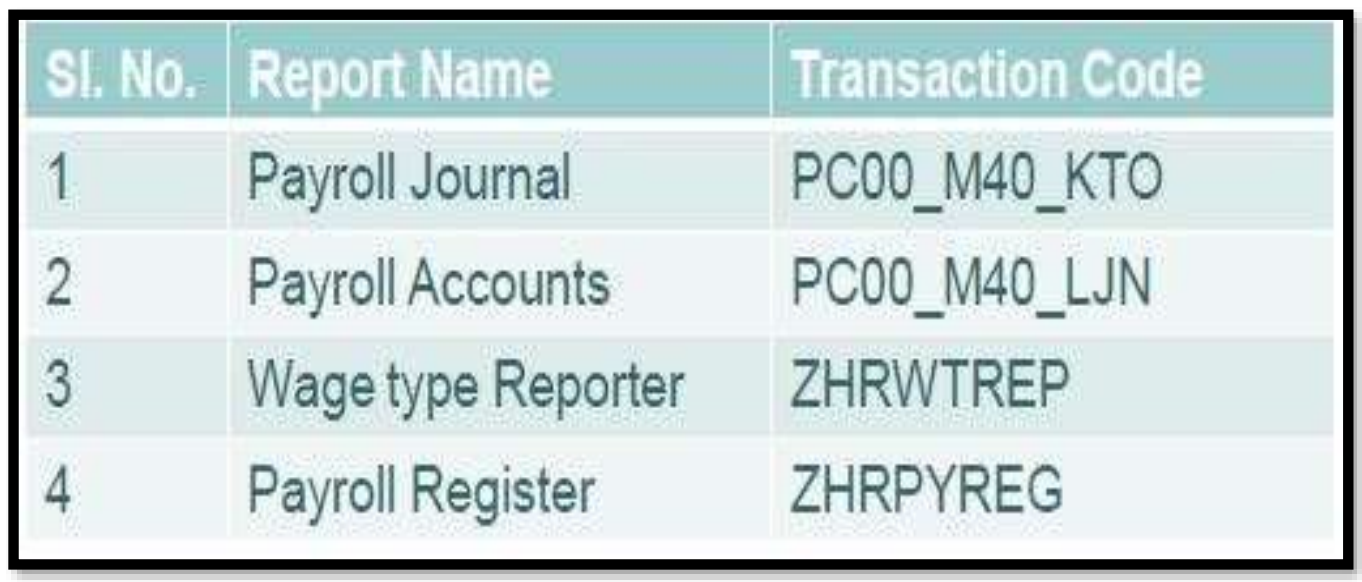

\section{Conclusion}

This paper clarifies the Payroll processing and HR solutions available in SAP (System Application Product) - ERP (enterprise Resource Planning), to assist internal and external needs of an organization. Payroll is country specific as it must be adapted to the laws and regulations of each particular country. Due to this country dependency, SAP has created a wage type catalog per country, as well as a country specific schema within the standard solution. SAP offers global Payroll solution and this global solution can be used for countries or as an example of re-usable development that can be adapted for those 
countries where a standard solution does not exist. The Payroll End user should now have the capacity to acknowledge and understand the Payroll processing and its requirements, payslip generation, postings to financial accounting, reports and other Payroll validations. The end user/client ought to likewise have the capacity to portray reporting and analysis solutions available in SAP ERP to support various internal and external reporting needs of an organization.

\section{References}

[1] P. Bernus, "GERAM: Generalised Enterprise Reference Architecture and Methodology", Google Scholar.

[2] B.F. Van Dongen, A.K.A. de Medeiros, H.M.W. Verbeek, A.J.M.M. Weijters and W.M.P. van der Aalst, "The ProM framework: A new era in process mining tool support", In: Ciardo, G., Darondeau, P. (eds.) ICATPN 2005. LNCS, Springer, Heidelberg, - Cross RefGoogle Scholar, vol. 3536, (2005), pp. 444-454.

[3] L. Silverston, "The Data Model Resource Book. A Library of Universal Data Models for all Enterprises", (revised edition) Google Scholar, vol. 1, (2001).

[4] B.F. Van Dongen, W.M.P. van der Aalst and H.M.W(E.) Verbeek, "Verification of ePCs: Using reduction rules and petri nets”, In: Pastor, Ó., Falcão e Cunha, J. (eds.) CAiSE 2005. LNCS, vol. 3520, pp. 372-386. Springer, Heidelberg, CrossRefGoogle Scholar, (2005).

[5] , B.F. Van Dongen and M.H. Vullers-Jansen, "EPC Verification in the ARIS for MySAP reference model database", In: BETA Working Paper Series, WP 142, Eindhoven University of Technology, Eindhoven, Google Scholar, (2005).

[6] P. Fettke and P.Loos, "Classification of Reference Models - a methodology and its application", Information Systems and e-Business Management, CrossRefGoogle Scholar, vol. 1, no. 1, (2003), pp. $35-53$.

[7] G. Keller, M. Nüttgens and A.W. Scheer, "SemantischeProcessmodellierung auf der GrundlageEreignisgesteuerterProcessketten (EPK)", In: Veröffentlichungen des InstitutsfürWirtschaftsinformatik, Heft 89 (in German), University of Saarland, SaarbrückenGoogle Scholar, (1992).

[8] G. Keller and T. Teufel, "SAP R/3 Process Oriented Implementation", Addison-Wesley, Reading, Google Scholar, (1998).

[9] F. Leymann and D. Roller, "Production Workflow: Concepts and Techniques", Prentice-Hall PTR, Englewood Cliffs, Google Scholar, (1999).

[10] , M. Rosemann, "Application Reference Models and Building Blocks for Management and Control (ERP systems)", Springer, Berlin, Google Scholar, (2003), pp. 595-616.

[11] M. Rosemann and W.M.P. van der Aalst, "A Configurable Reference Modelling Language. QUT Technical report", FIT-TR-2003-05, Queensland University of Technology, Brisbane, - Google Scholar, (2003).

[12] W. Sadiq and M.E. Orlowska, "Modeling and verification of workflow graphs. Technical Report No. 386", Department of Computer Science, The University of Queensland, Australia, Google Scholar, (1996).

[13] A.W. Scheer, "Business Process Engineering, Reference Models for Industrial Enterprises", Springer, BerlinGoogle Scholar, (1994).

[14] A.W. Scheer, "Business Process Modelling", 3rd edn., Google Scholar, (2000).

[15] L. Silverston, "The Data Model Resource Book. A Library of Data Models for Specific Industries", (revised edition)Google Scholar, vol. 2, (2001).

[16] SAP Library - Payroll India (PY-IN) - SAP Help Portal. https://help.sap.com/saphelp_erp2005/helpdata/en/72/.../frameset.htm.

[17] SAP HCM Payroll India - ERP Human Capital Management - SCN Wiki. https://wiki.scn.sap.com/wiki/display/ERPHCM/SAP+HCM+Payroll+India.

[18] SAP Library - Payroll India (PY-IN) - SAP Help Portal. help.sap.com/erp_hcm_ias_2013_02/helpdata/en/ac/.../frameset.htm. 


\section{Authors}

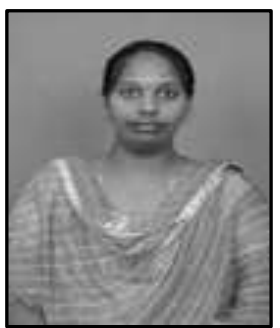

J. Anitha, she is working as Associate Professor in Vignan's Institute of Information Technology Vishakapatnam, Completed her M.Tech from Andhra University in the year 2007 \& Received her Doctrate from Andhra University in 2016.. Her Interests include Data Mining, Artificial Intelligence, Natural Language Processing.

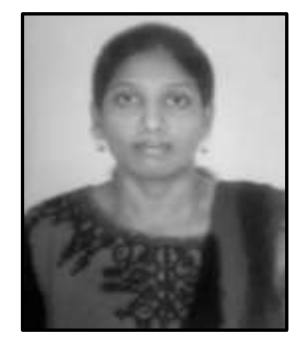

J. Saritha, she has done her MBA from Osmania University in the year 2004 and working as SAP HR consultant in SAR Payroll in ADP since 2008. Her area of interest is in payroll system. 